University of Wollongong

Research Online

Faculty of Law, Humanities and the Arts Papers (Archive)

$1-1-2018$

'A frivolous prosecution': Allegations of Physical and Sexual Abuse of Domestic Servants and the Defence of Colonial Patriarchy in Darwin and Singapore, 1880s-1930s

Claire K. Lowrie

University of Wollongong, clowrie@uow.edu.au

Follow this and additional works at: https://ro.uow.edu.au/lhapapers

Part of the Arts and Humanities Commons, and the Law Commons

Research Online is the open access institutional repository for the University of Wollongong. For further information contact the UOW Library: research-pubs@uow.edu.au 


\title{
'A frivolous prosecution': Allegations of Physical and Sexual Abuse of Domestic Servants and the Defence of Colonial Patriarchy in Darwin and Singapore, 1880s-1930s
}

\author{
Abstract \\ This chapter explores the relationship between domestic service, violence, and colonial masculinities in \\ the settler colony of Darwin and the exploitation colony of Singapore. The chapter analyses \\ representations of assault and abuse of domestic servants by their British, white Australian, and Chinese \\ masters in order to illuminate the ways in which violence could challenge or sustain colonial patriarchy. \\ The central argument is that the ways in which violence towards Chinese and Aboriginal servants was \\ either justified or ignored by the press, colonial officials, and ordinary colonists reflected an underlying \\ agenda to protect the reputation of ruling-class men and the colonial venture as a whole. By comparing \\ Darwin and Singapore, this chapter aims to illuminate the shared and particular preoccupations that \\ underpinned settler and non-settler colonial projects.
}

\section{Keywords}

singapore, darwin, patriarchy, colonial, defence, servants, domestic, abuse, sexual, physical, allegations, 1880s-1930s, prosecution':, 'a, frivolous

Disciplines

Arts and Humanities | Law

\section{Publication Details}

Lowrie, C. (2018). 'A frivolous prosecution': Allegations of Physical and Sexual Abuse of Domestic Servants and the Defence of Colonial Patriarchy in Darwin and Singapore, 1880s-1930s. In P. Edmonds \& A. Nettelbeck (Eds.), Intimacies of Violence in the Settler Colony: Economies of Dispossession around the Pacific Rim (p. 1). Cambridge: Palgrave Macmillan. 


\section{'A frivolous prosecution': Allegations of Physical and Sexual Abuse of Domestic Servants and the Defence of Colonial Patriarchy in Darwin and Singapore, 1880s- $1930 \mathrm{~s}^{1}$}

Claire Lowrie, University of Wollongong, Australia

Historians of domestic service have long asserted that exercising domestic mastery over colonised servants was considered to be an expression and a symbol of coloniser status. At the same time, intimate physical contact between 'native' servants and their employers could destabilise hierarchical distinctions, thereby threatening the stability of colonial rule. ${ }^{2}$ The potential for intimate relationships between employers and servants to affirm or contest colonial hierarchies has been richly demonstrated in the small body of work on violence within the colonial domestic service relationship. Historians of colonial Africa and the Pacific have illustrated how (real and imagined) incidents of physical and sexual assault of white employers by Indigenous and Asian domestic servants were interpreted as an attack on white

colonial power. ${ }^{3}$ At the same time, scholarship on India and Australia has considered how the notions of racial superiority on which colonial societies rested enabled and excused the physical and sexual abuse of Indigenous servants by their white employers. ${ }^{4}$ Gender has been a key concern within the literature on violence and domestic service, with much of the scholarship exploring how white women became the focus of colonial anxieties, either as victims of physical and sexual assault or as perpetrators of violence.

This chapter takes the literature in a new direction by exploring the relationship between domestic service, violence and colonial masculinities in the settler colony of Darwin and the exploitation colony of Singapore between the 1880s and the 1930s. By analysing the representations of assault and abuse of domestic servants by their British, white Australian 
and Chinese masters, the chapter aims to illuminate the ways in which violence could challenge or sustain colonial patriarchy. Colonial legitimacy in Darwin and Singapore, similarly with European colonial projects all over the world, rested on the belief that white men were inherently righteous and benevolent rulers of the home and the colony. ${ }^{5}$ Instances of white male violence towards colonised servants had the potential to unsettle such assertions.

My argument in this chapter is that the ways in which violence towards Chinese and Aboriginal servants was either justified or ignored by the press, colonial officials and ordinary colonists reflected an underlying agenda to protect the reputation of ruling-class men and the colonial venture as a whole. At the same time, I illustrate how the different status of Darwin as a part of a settler colony and Singapore as an exploitation colony ensured that the maintenance of colonial patriarchy played out in different ways. In Darwin, the aim of creating a white settler society ensured that the image of white men as firm yet fair employers of Chinese and Aboriginal servants prevailed despite evidence to the contrary. In Singapore, too, British masters were depicted as civilising and good even as they were convicted of assault of their Chinese houseboys. They were not, however, the only men whose kindly image was safeguarded. In Singapore, where the stability of colonial rule relied upon the cooperation of Chinese elites, the press and the government downplayed the abuse of young Chinese bonded servants (mui tsai) employed in Chinese homes.

By comparing representations of violence, gender and domestic mastery in Darwin and Singapore, this chapter aims to illuminate the shared and particular preoccupations and processes which underpinned settler and non-settler colonial projects. Specifically, I argue that race was the most important determiner of coloniser status in Darwin while in Singapore class and masculinity were more important. Thus in Singapore, middle- and upper-class 
Chinese men were depicted, alongside British men, as worthy masters and colonisers. In Darwin that status was reserved for white men and women only.

The level of documentation of violent assault by or towards domestic workers in Darwin and Singapore differs significantly. Research for this chapter uncovered a mere seven accounts of violence involving servants reported in Northern Territory newspapers including the Northern Territory Times, the Northern Standard and (in the South Australian period) the Register between 1880 and 1930. This compares with 41 incidents in Singapore's English language press including the Straits Times, the Singapore Free Press and Mercantile Advertiser and the Malaya Tribune. The differences in the number of reported court cases is a reflection of the larger population of Singapore compared to Darwin. It also reflects the larger size of the domestic servant workforce in Singapore. ${ }^{6}$

The reported accounts of assault and abuse examined in this chapter probably reflect only a small proportion of the violent altercations between employers and servants that took place. The unequal power dynamic at the heart of the master-servant relationship mediated against servants reporting their employers to the police for physical abuse. Even if they did take them to court the balance of the law was not in servants' favour. Under Masters and Servants laws for example, judges had the power to fine employers for mistreatment of servants but they tended to be more concerned with prosecuting servants who failed to deliver 'faithful service'. ${ }^{7}$ Even so, Chinese servants in Darwin and Singapore (like their counterparts in India and Hong Kong) sometimes turned to the law to redress their abuse by employers. ${ }^{8}$ Aboriginal servants in Darwin, it seems, did not. I uncovered no court cases brought by Aboriginal servants against their employers.

While the record is sparse and one-sided, a critical reading of the cases of physical and sexual assault reported in the press and discussed by colonial officials, together with an analysis of oral histories and memoirs from servants and employers, gives a good indication 
of how central violence was to the domestic service relationship. The ways in which violence perpetrated by white-Australian, British and Chinese men was reported, policed and remembered, as well as the ways in which it was ignored, erased and forgotten, provides insights into the relationship between colonial patriarchy and domestic service in settler and non-settler colonies.

\section{Settlers, servants and the connected histories of Darwin and Singapore}

In some ways Darwin and Singapore were very different colonies. Singapore's colonial history began in 1819 following the signing of a formal treaty with the Sultan of Johore. Singapore was an exploitation colony in which the aim of colonisation was to generate profits by extracting resources and exploiting migrant labour. ${ }^{9}$ The Northern Territory of Australia, of which Port Darwin was the capital, was intended to be a 'settler colony' in which the permanent settlement of British and white Australian colonists was pursued through the violent dispossession of the traditional owners of the land. ${ }^{10}$ In contrast to the negotiation of a treaty in the case of Singapore, the Northern Territory was considered to be a 'wilderness for

the taking' and Aboriginal people were treated accordingly. ${ }^{11}$ The contrasting objectives of British colonialism in Singapore and Darwin was solidified with Australian Federation in 1901 after which point the Northern Territory ceased to be a British colony and was subsumed into the Commonwealth of Australia.

While the underlying intentions of colonisation in Darwin and Singapore were very different, as neighbouring ports situated in the Southeast Asian region the colonies nonetheless had a good deal in common. The establishment of a settlement at Palmerston (as Darwin was original called) in 1869 was the fifth attempt to establish a northern trading outpost. The early residents of the town optimistically declared Darwin would become the 
'Singapore of Australia' and the port was initially exempt from customs duties in order to promote it as a free port like Singapore. ${ }^{12}$ The grand aspirations for Darwin did not eventuate with economic recession and population decline setting in by the 1890s. While Singapore rose to become one of the most successful port cities in Asia, Darwin remained a backwater. ${ }^{13}$ Nonetheless, Darwin and Singapore remained connected by movement of migrants, tourists and trade along the steam ship lines which linked the ports (see figure 1).

\section{[INSERT FIGURE 1 NEAR HERE]}

Figure 1. Burns Philp Steamship Line between Singapore and Darwin. Picturesque Travel, Burns Philp and Company, no. 6, 1925, National Library of Australia.

The different levels of success that Darwin and Singapore enjoyed as trading ports was reflected in the size of their populations. In 1911, Singapore's population reached 303,321 while Darwin's was a mere 1,387. Yet there were similarities in the ethnic composition of the populations. In 1911, ten years after the introduction of the White Australia Policy, Darwin's population, like that of Singapore, was multi-ethnic with the Chinese population still the largest ethnic group resident in the town. ${ }^{14}$ The ethnically diverse nature of Darwin's population calls into question its status a white settler colony. While distinctions between settler and non-settler colonies might illuminate the intentions of colonial projects, such categorisations do not always reflect the realities on the ground. ${ }^{15}$

The nature of Singapore's population also illustrates the unfixed and ambiguous nature of categories such as 'settler' versus 'exploitation' colonies. ${ }^{16}$ Many of the Chinese migrants who came to Singapore ended up settling permanently in the colony. ${ }^{17}$ By 1911 , the 
Chinese population of Singapore had stabilised at 72 per cent of the total population. ${ }^{18}$ Like Asian migrants resident in other European colonies, the Chinese community of Singapore was certainly oppressed by the white colonial state. Yet they were also colonists in their own right and were implicated in the colonial project. ${ }^{19}$ As advisors to the administration, Chinese elites in Singapore played a critical role in colonial governance helping to in keep the majority Chinese labouring population in check. ${ }^{20}$

The history of connection between Darwin and Singapore, their common status as tropical colonies and the similar nature of their multi-ethnic populations facilitated the development of a common colonial culture. In both sites colonial prestige was marked by the presence of numerous Asian and Indigenous servants in elite colonial homes. Chinese houseboys predominated in domestic service in Darwin and Singapore between the 1880s and 1910s. In Darwin by the 1920s, Aboriginal men and women as well as young mixed-descent girls came to dominate the servant class. In Singapore in the same period Chinese female servants called amahs gradually replaced Chinese men in service. In Chinese homes in Singapore, mui tsai (girl slaves) were also employed throughout the $1880 \mathrm{~s}$ and $1930 \mathrm{~s}^{21}$

As will be explored in the following discussion, the common ways in which violence by white male employers was legitimised or ignored in the two colonies illustrates the 'connective tissue' of gendered ideologies and the ways in which colonialism as a system rested on the maintenance of patriarchy. ${ }^{22}$ At the same time, however, the condemnation of Chinese employers of servants in Darwin, compared with the respect Chinese masters were accorded in Singapore, illustrates how conceptions of race and class shaped patriarchy in different ways in settler and exploitation colonies.

\section{A 'slight kick': Justifying white men's violence against Chinese houseboys, 1880s-1910s}


Between the 1880s and the 1910s accounts of violence by white men towards their Chinese servants were relatively common. In both sites, white men were charged and convicted for beating, slapping and kicking Chinese houseboys and other servants employed in the home. In Darwin in 1885 , a police constable by the name of Robert Stott defended himself against a charge of assault of his Chinese houseboy, Ah Lung, by claiming that his 'slight kick' was provoked by Ah Lung 'using a certain closet in a filthy manner'. Stott's use of the racist trope of Chinese people as dirty and unhygienic worked in his favour with the judge fining him a mere one pound for the assault and the newspaper dismissing the case as 'a most trumpery affair'. ${ }^{23}$ In Singapore a similar emphasis on white master's violence as justified prevailed. Cases of white men slapping or beating their Javanese and Chinese servants with belts and fishing rods were reported in sympathetic terms. Convictions for assault were described by journalists as 'frivolous prosecution[s]' while acts of violence were dismissed by judges as 'quite justified' or a result of 'grave and sudden provocation'. ${ }^{24}$

First-hand accounts from the Chinese servants who worked for British and white Australian men are incredibly rare. One of the only accounts that I am aware of is an oral history interview with Lim Ming Joon, a Hainanese man who worked as a servant in Singapore in the 1920s and 1930s. His account contests the idea that British men only responded with violence when justifiably provoked. Lim recalled a British male employer who became 'very angry' and 'threw a fit' when he was a few minutes late for work. Lim was forced to defend himself with a knife. ${ }^{25}$

Attitudes toward violence in colonial societies were complex and often contradictory. From the mid-nineteenth century in Britain and in the empire, respectable servant management involved a 'retreat from violence'. ${ }^{26}$ At the same time, the use of violence to discipline native servants was viewed in some circles as necessary and even appropriate. ${ }^{27}$ In the Philippines, Americans were forthright when it came to describing the use of force 
against their Filipino servants. They did not view violence in opposition to their stated goal of 'tutelage' and 'benevolent assimilation'. ${ }^{28}$ By the early twentieth century in British colonies, however, displays of violence were seen by colonial officials to call into question the legitimacy of the civilising mission and to violate the maintenance of physical distance between coloniser and the colonised. ${ }^{29}$ Displays of 'vulgar abuse' by white men also had the potential to unsettle the assertion that Anglo-Saxon men were biologically destined to rule due to their innate rationality and restraint. ${ }^{30}$ In this context the emphasis on white male violence as justified can be interpreted as an attempt to shore up white colonial and patriarchal authority.

The depiction of white masters as firm yet fair was reinforced by representations of acts of violence by white mistresses. In both Darwin and Singapore violence on the part of white women tended to be attributed to hysterical bursts of rage, particularly if the woman involved was working class. ${ }^{31}$ Such depictions reflected the anti-white women rhetoric which was aired across the tropical colonial world. The increasing numbers of white women visiting and settling in colonies across India, Africa, Asia and the Pacific from the late nineteenth century was viewed by colonial administrators as a welcome development. The imperialist and nationalist rhetoric of the era emphasised that white women's supposedly innate maternal influence would 'civilise' white colonial men and 'native' others. In the popular press, however, these women were often represented as 'idle memsahibs' who were incapable of managing 'native' servants and, by association, were ill equipped for colonial rule. ${ }^{32}$

The depiction of white male violence as justified also expressed and sought to resolve broader fears about the large and supposedly lawless Chinese populations of Darwin and Singapore. During in the 1880 s and 1890s colonial authorities in both sites depicted Chinese labourers as a criminal class. In Singapore, anxiety centred upon Chinese labourers' membership of so-called 'secret societies' (kongsi). In both sites, petty and violent crime in 
the colonies was attributed to the Chinese labouring classes and, in particular, their recreational activities which included opium consumption, gambling and frequenting brothels. ${ }^{33}$ In Darwin, concerns about crime were conflated with angst about growth of the Chinese population in what was supposed to be a 'white mans [sic] country'. ${ }^{34}$ In 1888 the Chinese population of the Northern Territory reached 7,000, outnumbering white colonists by four to one. ${ }^{35}$

As the labourers with whom Australian and British colonists were most intimate, Chinese houseboys came to embody white anxieties about the Chinese population. One of the attractions and obligations of the colonial venture for white men travelling to places like Darwin and Singapore was the experience of exercising 'personal authority' over colonised subjects. ${ }^{36}$ In their fictional accounts and travel stories, British and white Australian men described how the colonial experience, and their mastery over Asian and Indigenous servants in particular, transformed them from perfectly ordinary men into white masters. In Somerset Maugham's short story 'The Outstation', set in the remote jungles of Malaya and published in the 1920s, newly arrived British colonist, Warburton, revelled in the fact that 'he was no longer the sycophant craving the smiles of the great, he was the master whose word was law' ${ }^{37}$ Likewise, in Capricornia, his novel based on his time working as the Chief Protector of Aborigines in Darwin in the 1920s, Xavier Herbert cynically described how middle-class men from the southern regions of Australia transformed themselves into aristocratic gentlemen after arriving in the town by engaging Chinese domestic staff and by acquiring the appropriate tropical attire. As he put it: 'Within two dozen hours of landing they were wearing solar topees ...Within a hundred hours they came forth in all the glory of starched white linen clothes. Gone was their simplicity forever. ${ }^{38}$

The British and white Australian men who constituted the main employers of Chinese male servants in this era did not, however, always encounter the loyal and devoted Chinese 
houseboys of their imaginings. Chinese male servants were regularly accused of stealing from and, occasionally, violently assaulting their white male employers. ${ }^{39}$ In Singapore, accounts of Chinese servants 'running amok', attacking and sometimes murdering their Chinese employers reinforced a general fear of the Chinese servant class. ${ }^{40}$ In Darwin, too, the potential of disgruntled servants to lash out at their employers was the subject of press comment. ${ }^{41}$ As much as it was a means through which white masculinity was affirmed then, the colonial experience also exposed its vulnerability and insecurity. ${ }^{42}$ In Darwin and Singapore, white men's anxieties about their own violence and potential violence from their Chinese male servants was resolved by employing the same strategy. As we have seen, white men were depicted in newspaper accounts of violence against servants as rational bearers of justice whose discipline was directed at taming savage Chinese men. While the rhetorical strategies for dealing with the perceived problem of Chinese criminality were the same, the governmental responses to this issue were very different and reflected the divergent aims of settler and exploitation colonialism.

\section{[INSERT FIGURE 2 NEAR HERE]}

Figure 2. 'Chinese Boy on duty', Lambert and Co, Singapore, c. 1900, Royal Netherlands Institute of Southeast Asian and Caribbean Studies.

In the Northern Territory, the introduction of immigration restriction by the South Australian administration in 1888 and the passing of the white Australia policy in 1901 ensured that the Chinese population declined dramatically. ${ }^{43}$ The beginning of the Commonwealth administration in 1911 brought with it new mechanisms designed to 
marginalise the Chinese labouring community economically as well as diminishing their numbers through strict adherence to immigration restriction. ${ }^{44}$ As the Chinese servants who had been such an essential part of white households were largely forced from the town, discussions of violence by and towards Chinese male servants disappeared. While a number of white Territorians lamented the decline of Chinese houseboys, occasional reports of acts of violence by the remaining few Chinese servants resident in the Northern Territory and by those employed in other parts of Australia and Asia perhaps soothed other white Territorians that their 'Chinese problem' had been resolved. ${ }^{45}$

In Singapore, rather than alienating and excluding the entire Chinese population, the colonial government sought to assert control over labouring Chinese by collaborating with elite Chinese merchants (towkays) and the English speaking Straits Chinese community. ${ }^{46}$ In addition, the government banned kongsi organisations in 1890 and began regulating brothel prostitution and the production and sale of opium. ${ }^{47}$ The administration also targeted the Chinese servant class specifically, attempting to introduce the registration of domestic servants in 1888 in order to provide employers with information about their servant's personal and criminal histories. ${ }^{48}$ Further calls for the introduction of servant registration followed, but was never instituted. While in Darwin concerns about the Chinese servant class disappeared from public commentary, in Singapore a new threat of politically inspired violence by Chinese male servants emerged during the 1920 s. ${ }^{49}$ Like colonial administrators in Darwin, the Straits Settlements sought to deal with this 'Chinese problem' through immigration control. Rather than creating a nation for the white man, however, the intention was to exclude those 'likely to promote sedition or to cause a disturbance of public tranquillity' with Chinese male servants signalled for particular attention. ${ }^{50}$ 


\section{'... a form of cruelty not easily detected': Ignoring the abuse of Aboriginal servants in white Australian homes and mui tsai in Chinese homes, 1910s-1930s}

Between the 1880s and the 1910s popular representations of violence by British and white Australian masters emphasised assault and abuse as a legitimate means of disciplining unwieldy Chinese servants. By the 1920s strategies for defending ruling-class men's violence had changed. The 1920s and 1930s was a period of growing humanitarian critique with the alleged exploitation of Aboriginal servants employed in white homes in Darwin, and the abuse mui tsai (girl slaves) working in Chinese homes in Singapore, targeted for comment. Rather than confront the allegations, government officials and the local press remained silent to protect and defend the reputation of white Australian men in Darwin and middle-class Chinese men in Singapore. Preserving the image of these men as good masters and good colonisers was essential to achieving the settler colonial project in Darwin and to ensuring the long-term stability of exploitation colonialism in Singapore.

From the 1910s governmental efforts to transform the multi-ethnic north into a bustling site of white settlement stepped up pace. While immigration restriction had largely solved the perceived problem of Chinese settlement in the Northern Territory, the persistence of Indigenous communities and the emergence of a mixed-race population were seen as an obstacle to achieving a white Australia in the north. ${ }^{51}$ The Commonwealth government's Aboriginal Ordinances of 1911 and 1918 sought to resolve the so-called 'half-caste problem' by removing mixed-descent children from their families and communities and assimilating them into white society. In aid of this objective, mixed-descent boys were trained as farm labourers while girls were recruited into domestic service. Prospective white employers had to apply to for a license to employ Aboriginal and mixed-descent servants in their homes. ${ }^{52}$

While this system of Aboriginal employment was lauded by the Commonwealth administration as the ideal means of 'protecting' Aboriginal people and assimilating the 
mixed-descent community, it was criticised by some commentators within Australia and overseas. The fact that Aboriginal and mixed-descent servants were compelled to work as servants for white employers and received little or no remuneration for their work ensured the licensing system was condemned in London and Europe as one of 'slave certificates'. 53 Australian missionaries and feminists also condemned the conditions of Aboriginal employment as 'analogous to slavery' and warned of the potential for violence against and sexual abuse of mixed-descent servant girls by white male employers. ${ }^{54}$

Despite the national and international context of debate, instances of abuse of Aboriginal domestic workers were not discussed by the press in Northern Territory and were only rarely the subject of official comment. Nor did employers (either at the time or later in oral history accounts) acknowledge violence and exploitation. ${ }^{55}$ Where the issue of violence or abuse involving Aboriginal and mixed-descent domestic servants was raised it was in relation to their alleged abuse by Chinese employers prior introduction of the South Australian administration's Aborigines Act of 1910 which first banned the employment of Aboriginal and mixed-descent people by 'Asiatics' ${ }^{56}$ In contrast to Chinese masters, white Australian mistresses in particular were depicted as civilizing and protecting. ${ }^{57}$ As Victoria Haskins has shown, this image of the kindly white mistress was used by government officials in the Northern Territory and across Australia to justify the forcible removal of Aboriginal children from their communities and their so-called 'apprenticeship' in white homes. ${ }^{58}$ The image of the benevolent and paternal white employer was also of vital importance in justifying the pursuit of a white Australia in the tropical north. This is illustrated by the ways white male violence towards Aboriginal servants was intentionally obscured in Darwin. 
Figure 3. Margaret Gilruth sitting on steps outside Government House with an unnamed Aboriginal maid servant and Billy Shepherd, Darwin, c. 1912-1918, Jean A. Austin Collection, Northern Territory Library.

The attempt to ignore and silence accounts of violence by white men towards their Aboriginal servants in the Northern Territory is demonstrated by the story of an Aboriginal man called Romula employed on Oenpelli Station. In 1917 Romula was convicted of attempting to murder his employer, Patrick Cahill, and the entire Cahill family by adding strychnine to the butter. While the case was briefly discussed in the Annual Report for the Northern Territory in 1917 it received no coverage in the local press. ${ }^{59}$ The entire incident may well have been forgotten were it not for the Royal Commission on corruption in the administration of the Northern Territory which ran from 1920 to 1921 . While the local press in Darwin continued to ignore the case, journalists elsewhere detailed the failure of the justice system to adequately defend Romula. Newspaper articles from around Australia also documented Cahill's violent response to the poisoning, describing how he had chained and whipped Romula and the mixed-descent cook, Jimmy Ah Foo. ${ }^{60}$

The reluctance to discuss the case in the Northern Territory reflects the anxieties that surrounded Aboriginal men who transgressed the role of passivity and powerlessness which colonial discourses had allocated them. ${ }^{61}$ While we do not know Romula's motivation in poisoning Cahill, his attempt to murder the mission manager would surely have been read as a challenge to colonial power in the Northern Territory. On the other hand, other cases where the behaviour of Aboriginal men exposed the myth of their harmless and passive nature did receive attention in the local press. ${ }^{62}$ The key reason for the reluctance to engage with this case related to the actions of Cahill. The image of a white employer chaining and whipping 
his Aboriginal and Chinese servants was the absolute opposite of restrained civility and fatherly care befitting of a white master and coloniser. It seemed to confirm the accusations levelled at white employers of Aboriginal servant as slave owners. In a report to the government, Cahill attempted to restore his reputation as a kindly white master by claiming that Romula had poisoned him because he was trying to stamp out the practice of 'wife beating' amongst the Aboriginal men on the station. The Northern Territory Times's support for this version of events is illustrated by their decision to republish the report. ${ }^{63}$

A desire to protect the image of white men in the Northern Territory can also be seen in the reporting of instances of sexual abuse of mixed-descent girls in service. Oral history accounts from women who worked as domestic servants in Darwin indicate that the threat of sexual abuse was part of life as a domestic servant. ${ }^{64}$ Public awareness of the issue of sexual abuse is demonstrated by the campaigns of feminist groups for white women to be appointed as Aboriginal Protectors and to be given powers to inspect the conditions in which mixeddescent girls were employed. ${ }^{65}$ The reluctance of the Commonwealth administration to act on such requests illustrates the desire to avoid the implication that, as Fiona Paisley puts it, 'white men were the problem on the frontier'. ${ }^{66}$ In Darwin, the reluctance to discuss potential and actual incidences of abuse of Aboriginal servants in white homes reflects a desire to protect the image of white men as good masters, good colonisers and the rightful inheritors of the land.

The only article I have located that delved into the issue focused not on the sexual exploitation of Aboriginal servants but on a 'rumour' that a named mixed-descent woman had murdered her new born baby. Implied within the discussion of the article was the suggestion that mixed-descent Aboriginal servants were regularly involved in sexual relationships with their male employers, though there was no suggestion of coercion. ${ }^{67}$ The widely accepted view of white Australians in this period that mixed-descent women were 
sexually promiscuous served to absolve white employers of guilt. ${ }^{68}$ That the article was published in 1935 at a time when assimilation took on increasingly eugenic undertones with the aim of breeding out colour perhaps also explains the lack of public outrage and action. ${ }^{69}$

While in Darwin humanitarian critique surrounded Aboriginal employment in white homes, in Singapore the position of mui tsai (girl slaves) employed in Chinese homes was subjected to intense international scrutiny. The mui tsai practice was a tradition that Chinese migrants had brought with them to Singapore and involved impoverished Chinese families selling their daughters into servitude. On reaching puberty mui tsai were married off, became concubines, or were resold, sometimes to brothels. ${ }^{70}$ During the 1920s and 1930s the Chinese republican government, the League of Nations slavery committees, the British Aborigines Protection League and various missionary organisations based in London and China labelled the practice child slavery and called for its abolition within the Straits Settlements, Malaya and Hong Kong. ${ }^{71}$ The Straits Settlements government sought 'remove any vestige of doubt ... that slavery ... is tolerated in this Colony' by making superficial changes to transform the system into a form of domestic apprenticeship. ${ }^{72}$ The most significant piece of legislation was the Mui Tsai Ordinance of 1933 which required the registration of all existing mui tsai, the payment of a small wage and regular inspections of their working conditions. The legislation failed to bring the practice to an end with owners disguising their mui tsai as family members or simply refusing to register them. ${ }^{73}$ Further action was taken with the commissioning of a report on the mui tsai in 1937 in which it was argued that most mui tsai now worked for their employers as free servants and were generally well cared for. In contrast to the 'Majority Report', Edith Picton-Turbervill's 'Minority Report' maintained that the system and its abuses were ongoing. Picton-Turberville gave evidence that beating mui tsai was commonplace and, while it was difficult to document that 'form of cruelty not easily 
detected', the notions of ownership on which the practice rested increased the potential for sexual abuse. ${ }^{74}$

Very few of the oral histories and memoirs from Chinese people who employed mui tsai in 1920s and 1930s Singapore detail abuse, with most maintaining that mui tsai were treated as part of the family. ${ }^{75}$ Yet the accounts of former mui tsai, such as Janet Lim, confirm the Picton-Turberville's assessment that because the mui tsai was a 'slave' who 'had been purchased', 'the master could do whatever he pleased with her'. ${ }^{76}$ Mui tsai who suffered physical and sexual abuse had little opportunity for redress as the Chinese patriarchal system allocated women roles as domestic drudges, child bearers and sex objects. ${ }^{77}$

Despite the international anti-mui tsai campaign which drew attention to the systematic abuse of these servants, there was reluctance in Singapore to condemn the Chinese employers of mui tsai. In Singapore during the 1920s and 1930s, the reporting of murder, attempted murder, battery and sexual assault variously perpetrated by Hainanese houseboys, British memsahibs or Eurasian masters was at a peak. ${ }^{78}$ In Hong Kong stories of 'callous mistress[es]' violently abusing mui tsai occasionally featured in the local European newspapers. ${ }^{79}$ In Singapore, however, there was a marked absence of accusations of abuse of servants within Chinese homes. Journalists, like government officials and even anti mui tsai campaigners, were influenced by the arguments made by Chinese employers that the mui tsai were treated as family members rather than slaves and were rarely abused. ${ }^{80}$

While upper and middle-class Chinese employers of servants were generally spared the critical gaze of newspaper reporters, one incident involving the beating of a 'Chinese servant maid' who may have been a mui tsai was reported in the Straits Times in 1909. The focus of the case and the article was not, however, on the assault of Wee Ah Hoh by her Chinese master Hoh Sang Lim, a wealthy towkay (merchant). Rather, the case was brought 
against Wee for attempting suicide. She was convicted and sentenced to fourteen days imprisonment. ${ }^{81}$

It was not until 1937 in the context of Picton-Turberville's minority report and subsequent publications on abuses of mui tsai by Sir George Maxwell, a former colonial administrator in Malaya, that the Straits Times acknowledged a previous 'indifference' towards the mui tsai issue. The paper resolved to bring to light 'allegations of shocking cruelty' and the 'dangers and evils that are inherent in this custom'. ${ }^{82}$ The Straits Settlements government too made further attempts to end the mui tsai practice with the Children's Ordinance of 1938-1940. However, the outbreak of World War II ensured it was never instituted. $^{83}$

Sarah Paddle attributes the lack of hysteria during the mui tsai controversy to the 'internationalist and racially aware' western feminist movement. ${ }^{84}$ For the press and the colonial government in Singapore the display of cultural sensitivity also had a practical purpose. The reluctance of the British to condemn respectable Chinese for keeping mui tsai needs to be read in the context of a majority Chinese population and Chinese elite with close ties to the government. For European colonisers, to be a good and worthy master was to be a good and worthy coloniser. To exclude the Chinese from the status of respectable mastery was to exclude them from coloniser status. This would allocate the British a long-term moral responsibility for the colony, a situation that was not consistent with their colonial objectives. As the Acting Secretary of the Straits Settlements Hayes Marriott put it in 1921, it was the Chinese community rather than the British who 'look upon this Settlement as their home' and 'form a permanent population' in Singapore. ${ }^{85}$ The cultural sensitivity displayed by the British in Singapore was in their own best interests, providing a means to maintain colonial stability and business as usual. 


\section{Conclusion}

The representation of violence perpetrated by British, white-Australian and Chinese men against their servants in Darwin and Singapore underwent considerable change between the 1880 s and the 1930s. During the 1880s and to the 1910s, convictions of white men for assault of their Chinese houseboys were regularly reported in the local papers. In the context of widespread anxiety about the large numbers of Chinese labourers within the colonies and their supposed predilection for crime; beating, slapping and kicking Chinese servants was envisioned as an appropriate form of servant discipline and a reasonable means of demonstrating white men's status as rulers. Thus, despite the contrasting objectives of settler colonialism in Darwin and exploitation colonialism in Singapore, the potential threat which white male violence presented to the colonial civilising mission was conceived of and resolved in very similar ways. Ultimately, the colonial governments of Darwin and Singapore also sought to resolve the perceived problem of Chinese criminality in the same way, using immigration controls to exclude the migration of Chinese male workers. In Darwin, however, the intent of immigration restriction was to create a 'white man's country' while in Singapore the aim was to achieve political stability so that profits might keep flowing back to London.

By the 1920s and 1930s the reporting of violence by white masters disappeared almost entirely. In the context of widespread humanitarian critique of colonialism, government officials and the press in Singapore and Darwin were careful to protect the reputation of white masters as representatives of colonial legitimacy. Thus, the press in Darwin refused to engage with the allegations of white men violently assaulting and sexually abusing Aboriginal servants that were reported in newspapers in south-eastern Australia and overseas. In Darwin, discussing the potential for white men to abuse Aboriginal servants was seen to risk the future of the colony. The justification for the domestic indenture of Aboriginal and mixed-descent people rested upon white colonial patriarchy with a 
paternalistic white master and a kindly white mistress responsible for assimilating Aboriginal people into the white settler nation.

In Singapore in the 1920s and 1930s, the racialised and gendered image of British men as good masters and good colonisers was reinforced by salacious accounts of savage white memsahibs and uncivilised Eurasian masters abusing their servants. At the same time, there was marked silence in the press regarding the allegations of exploitation and abuse of mui tsai in Chinese homes which were being aired in Hong Kong and London. In Singapore, condemning Chinese masters for abusing mui tsai had the potential to alienate the elite Chinese on whom colonial stability in part rested and thus risked the future of the colony.

An analysis of the ways in which violence by employers of servants was represented by the press, colonial governments and ordinary colonists illustrates the central yet distinct way in which colonial patriarchy operated in settler and non-settler colonies. In Darwin colonial legitimacy rested upon defending white men from accusations of violence. In Singapore, middle- and upper-class Chinese men were also represented as respectable and restrained masters and, by implication, worthy colonisers.

\section{Notes}

${ }^{1}$ I would like to thank the anonymous reviewer for the critical and helpful feedback on this chapter.

${ }^{2}$ Ann Laura Stoler, Carnal Knowledge and Imperial Power (Berkeley: University of California Press, 2002), 6, 8.

${ }^{3}$ Jeremy Martens, 'Settler Homes, Manhood and 'Houseboys': An Analysis of Natal's Rape Scare of 1886', Journal of Southern African Studies 28, no. 2 (2002): 369; Prinisha Badassy, 
““And My Blood Became Hot!”: Crimes of Passion, Crimes of Reason: An Analysis of the Crimes of Murder and Physcial Assault against Masters and Mistresses by Their Indian Domestic Servants, Natal, 1880-1920', Journal of Natal and Zulu History 23, no. 1 (2006): 73-106; Amirah Inglis, The White Women's Protection Ordinance: Sexual Anxiety and Politics in Papua (London: Sussex University Press, 1975), 54-5, 65-6.

${ }^{4}$ Jordanna Bailkin, 'The Boot and the Spleen: When was murder possible in British India?', Comparative Studies in Society and History 48, no. 2 (2006): 472-88; Fae Dussart, "“Strictly Legal Means": Assault, Abuse and the Limits of Acceptable Behaviour in the Servant/Employer Relationship in Metropole and Colony 1850-1890', in Colonization and Domestic Service: Contemporary and Historical Perspectives, ed. Victoria Haskins and Claire Lowrie (New York: Routledge, 2015), 153-71; Victoria Haskins, “"Down the Gully and Just Outside the Garden Walk": White Women and the Sexual Abuse of Aboringial Women on a Colonial Frontier', History Australia 10, no. 1 (2013): 11-15.

${ }^{5}$ Mrinalini Sinha, 'Giving Masculinity a History: Some Contributions from the Historiography of Colonial India', Gender and History 11, no. 3 (1999): 447. ${ }^{6}$ In Singapore in 1921, 19,369 domestic servants were employed. This compares with 212 servants in the Northern Territory. This figure does not include the substantial number of Aboriginal servants employed in the Northern Territory who were not counted in the census. J.E. Nathan, The Census of British Malaya 1921 (London: Waterlow and Sons, 1922), 118; Chas. H. Wickens, Census of the Commonwealth of Australia 1921: Part XVII Occupations, 1250.

${ }^{7}$ B.W. Higman, Domestic Service in Australia (Melbourne: Melbourne University Press, 2002), 175-81. 
${ }^{8}$ Christopher Munn, 'Hong Kong, 1841 - 1870: All the Servants in Prison and Nobody to Take Care of the House', in Masters, Servants, and Magistrates in Britain and the Empire, 1562-1955, ed. Douglas Hay and Paul Craven (Chapel Hill: University of North Carolina Press, 2004), 366, 387; Dussart, “"Strictly Legal Means”", 159.

${ }^{9}$ Ann Laura Stoler, 'Tense and Tender Ties: The Politics of Comparison in North American History and (Post) Colonial Studies', Journal of American History 88, no. 3 (2001): 456.

${ }^{10}$ Haunani-Kay Trask, From a Native Daughter: Colonialism and Sovereignty in Hawai' $i$ (Honolulu: University of Hawai'i Press, 1993), 25.

${ }^{11}$ Alan Powell, Far Country: A Short History of the Northern Territory (Melbourne: Melbourne University Press, 1988), 52.

${ }^{12}$ Alfred Searcy, In Northern Seas (Darwin: Northern Territory Department of Education, 1984), 70.

${ }^{13}$ David Carment, “"A De Facto Australasia”: Darwin, Asia and the Australian Identity', Northern Perspective 18, no. 1 (1995): 8; C. M. Turnbull, A History of Singapore, 1819-1975 (Kuala Lumpur: Oxford University Press, 1977), 88-91.

14 'Census Figures for Darwin, 1911', National Archives of Australia (hereafter NAA) A1/15, 11/16191, (1911).

${ }^{15}$ Adele Perry, 'The State of Empire: Reproducing Colonialism in British Columbia, 18491871', Colonialism and Colonial History 2, no. 2 (2001).

${ }^{16}$ Daiva Stasiulis and Nira Yuval-Davis, 'Introduction: Beyond Dicotomies', in Unsettling Settler Societies: Articulations of Gender, Race, Ethnicity and Class, ed. Daiva Stasiulis and Nira Yuval-Davis (London: Sage, 1995), 3. 
${ }^{17}$ Christopher Lloyd and Jacob Metzer, 'Settler Colonization and Societies in World History: Patterns and Concepts', in Settler Economies in World History, ed. Christopher Lloyd, Jacob Metzer and Richard Sutch (Leiden: Koninklijke and Brill, 2013), 3.

${ }^{18}$ Hayes Marriott, 'The Peoples of Singapore: Inhabitants and Population', in One Hundred Years of Singapore, ed. Walter Makepeace, Gilbert Brooke and Roland Braddell (Singapore: Oxford University Press, 1991), 360.

${ }^{19}$ Ann Curthoys, 'An Uneasy Conversation: The Multicultural and the Indigenous', in Race, Colour and Identity in Australia and New Zealand, ed. John Docker and Gerhard Fischer (Sydney: University of NSW Press, 2000), 32.

${ }^{20}$ Edwin Lee, The British as Rulers Governing Multiracial Singapore 1867-1914 (Singapore: Singapore University Press, 1991), 91-2, 288.

${ }^{21}$ Claire Lowrie, Masters and Servants: Cultures of Empire in the Tropics (Manchester: Manchester University Press, 2016), 29-32.

${ }^{22}$ Penny Edwards, 'Mixed Metaphors: Other Mothers, Dangerous Daughters and the Rhetoric of Child Removal in Burma, Australia and Indochina', Balayi: Culture, Law and Colonialism 6 (2004): 42.

23 'News and Notes', Northern Territory Times and Gazette, 17 January 1885.

${ }^{24}$ Singapore Free Press and Mercantile Advertiser, 22 September 1891; 'A Frivolous Prosecution: Justification for Striking a Javanese Servant', Straits Times, 21 June 1909; ‘Taiping Topics', Malaya Tribune, 15 May 1914; ‘A Troublesome Amah', Singapore Free Press and Mercantile Advertiser, 7 May 1915; 'A Technical Assult', Singapore Free Press and Mercantile Advertiser, 4 July 1923.

25 'Transcript of Interview with Lim Ming Joon', National Archives of Singapore (hereafter NAS), ACC 000334/07, 25-6. Translated from Mandarin to English by EthnoLink Language 
Services, certified by the National Accreditation Authority for Translators and Interpreters (NAATI), http://www.ethnolink.com.au/translation/naati-accredited-certified-translationsaustralia.

${ }^{26}$ Dussart, "'Strictly Legal Means"”, 157.

${ }^{27}$ Bailkin, 'The Boot and the Spleen', 463-4.

${ }^{28}$ Sarah Steinbock-Pratt, “"We were all Robinson Crusoes”: American Women Teachers in the Philippines', Women's Studies 41, no. 4 (2012): 382-4.

${ }^{29}$ E.M. Collingham, Imperial Bodies: The Physical Experience of the Raj, C. 1800-1947 (Cambridge: Polity Press, 2001), 110-11.

${ }^{30}$ John Thomson, The Straits of Malacca, Indo-China and China (London: Sampson, Low, Marston, Low and Searle, 1875), 71-2; John Tosh, Manliness and Masculinities in Nineteenth Century Britain: Essays on Gender, Family and Empire (New York: Pearson Longman, 2005), 193-7.

${ }^{31}$ For Darwin, see 'Law Courts: Police Court, Palmerston', Northern Territory Times and Gazette, 14 January 1882. For Singapore, see 'Labu Assault Case: European Lady Charged', Singapore Free Press and Mercantile Advertiser, 1 April 1924; Straits Times, 13 January 1927; ““Mem” Fined for Striking Cook’, Straits Times, 19 June 1937.

${ }^{32}$ Claudia Knapman, White Women in Fiji, 1835-1930: The Ruin of Empire? (Sydney: Allen and Unwin, 1986), 19; Lowrie, Masters and Servants, 136-43.

${ }^{33}$ Carl Trocki, Opium and Empire: Chinese Society in Colonial Singapore, 1800-1910 (Ithaca: Cornell University Press, 1990), 11.

34 'Letter to the Editor', Northern Territory Times and Gazette, 12 February 1881; Northern Territory Times, 6 October 1883; 'European or Chinese Labor', Northern Territory Times and Gazette, 4 May 1889. 
${ }^{35}$ Glenice Yee, Through Chinese Eyes: The Chinese Experience in the Northern Territory, 1874-2004 (Parap: Glenice Yee, 2006), 38.

${ }^{36}$ Tosh, Manliness and Masculinities, 199-200; Powell, Far Country, 123-4.

${ }^{37}$ Somerset Maugham, The Casuarina Tree: Six Stories (London: Heinemann, 1926), 117.

${ }^{38}$ Xavier Herbert, Capricornia (Sydney: Angus and Robertson, 1987), 8, 10.

${ }^{39}$ For Darwin, see, 'Legal Information: Police Court', North Australia, March 18 1888;

'Chinese Secret Societies', South Australian Register, July 23 1891; 'Opium Smuggling:

Chinese Cook Heavily Fined', The Advertiser, May 19 1909. 'Inspector of Police to

Government Resident', 1887, Government Resident of the Northern Territory (South Australia), List of Inwards Correspondence, 1870-1911, Northern Territory Archives Service (hereafter NTAS), NTRS829, A9768. For Singapore, see Jonas Daniel Vaughan, The Manners and Customs of the Chinese of the Straits Settlements (Singapore: Mission Press, 1879); ‘A Dishonest Boy’, Straits Times, 4 July 1899.

${ }^{40}$ Ong Siang Song, One Hundred Years' History of the Chinese in Singapore (Singapore: Oxford University Press, 1984), 265; “A Ferocious “Boy'”, Straits Times, 1 July 1899; 'Three Tragedies: Angus Street Murder', Singapore Free Press and Mercantile Advertiser, 17 June 1909; 'Murderous Assault: Hylam Servant Attacks Master', Malaya Tribune 26 September 1919.

41 'Law Courts: Police Court, Palmerston',Northern Territory Times and Gazette, 14 January 1882.

${ }^{42}$ Warwick Anderson, 'The Trespass Speaks: White Masculinity and Colonial Breakdown', The American Historical Review 102, no. 5 (1997): 1343.

${ }^{43}$ Henry Reynolds, North of Capricorn: The Untold Story of Australia's North (Sydney: Allen and Unwin, 2003), 107. 
${ }^{44}$ Powell, Far Country, 156.

45 'Murdered by a Chinese Cook: Waiter's Head Beaten In', The Advertiser, 5 March 1906;

'Seven Persons Killed: A Cook's Revenge', Northern Standard, 29 April 1930; 'Station Hand Shot: Chinese Cook Imprisoned', The Advertiser, 21 April 1926.

${ }^{46}$ Ching-Hwang Yen, 'Class Structure and Social Mobility in the Chinese Community in Singapore and Malaya 1800-1911', Modern Asian Studies 21, no. 3 (1987): 427.

${ }^{47}$ Trocki, Opium and Empire, 183-5.

${ }^{48}$ Song, One Hundred Years.

${ }^{49}$ Lowrie, Masters and Servants, 143-147

${ }^{50}$ Joyce Ee, 'Chinese Migration to Singapore, 1896-1941', Journal of Southeast Asian History 2, no. 1 (1961): 42.

${ }^{51}$ Tony Austin, “"A Chance to Be Decent”: Northern Territory "Half-Caste” Girls in Service in South Australia 1916-1939', Labour History 60 (1990): 52-3.

${ }^{52}$ Austin, "“A Chance to Be Decent"”: 52-3.

53 'The Black Man's Burden', Sunday Express, 3 June 1934; 'Alleged Ill-Treatment of Natives Nt—Reports by Foreign Newspapers', NAA: A1/15, 1934/8852 (1934).

${ }^{54}$ Mary Montogomery Bennett, The Australian Aboriginal as a Human Being (London: Alston Rivers, 1930); Alfred H. Brown, Report on Some Problems of Northern Australia (Australia: Religious Society of Friends (Quakers) in Australia, 1914), 131.

${ }^{55}$ Of the sixteen employers accounts that I accessed only two mentioned violence between Aboriginal servants and none suggested employer-servant violence. 'Transcript of Interview with Betty Dangerfield', NTAS: NTRS 226, TS 187(1982), tape 1, 9; 'Transcript of Interview with W.E (Bill) Eacott', NTAS: NTRS 226, TS 758(1992), tape 1, 11-12. 
56 'Annual Report of the Northern Territory’, (Commonwealth Government of Australia, 1912), 48; 'The Discouragement of White Labor: Cruelty to Natives', Northern Standard, 25 April 1922; 'Starving Blacks: To the Editor', Northern Standard, 19 April 1925.

${ }^{57}$ Claire Lowrie, 'The Transcolonial Politics of Chinese Domestic Mastery in Singapore and Darwin 1910s-1930s', Journal of Colonialism and Colonial History 12, no. 3 (2011).

${ }^{58}$ Victoria Haskins, 'Domestic Service and Frontier Feminism: The Call for a Woman Visitor to 'Half-Caste' Girls and Women in Domestic Service, 1925-1928', Frontiers 28, no. 1/2 (2007): 127.

${ }^{59}$ Northern Territory of Australia: Report of the Administrator for the Years 1915-1916 and 1916-1917, National Library of Australia (hereafter NLA), nla.obj-54061288, 45, 47.

${ }^{60}$ See for example, 'The Natives: Revelations at Federal Inquiry', Sydney Morning Herald, 20 January 1920; 'In Territoria: Trial of Prisoners, Peculiar Court Methods', Daily Standard, 31 March 1917; 'Darwin Doings: Missing Documents, an Aborigines Plea', Register, 1 January 1920; ‘The Darwin Inquiry: Investigation Regarding Administration', Queenslander, 10 January 1920.

${ }^{61}$ Victoria Haskins and John Maynard, 'Sex, Race and Power: Aboriginal Men and White Women in Australian History', Australian Historical Studies 126 (2005): 42.

${ }^{62}$ For example, the attempted sexual assault of a white woman by an Aboriginal courier called Packsaddle in 1938. Fiona Paisley, 'Race Hysteria, Darwin 1938', Australian Feminist Studies 16, no. 34 (2001): 43.

63 'Oenpelli Blacks: Gins Get a Few Strokes', Northern Territory Times and Gazette, 3 January 1920. 64 'Transcript of Interview with Dolly Bonson', NTAS: NTRS 266, TS 429/2(1982), tape 1, 12; 'Transcript of Interview with Hilda Muir', NTAS: NTRS 226, TS 793(1993), tape 1, 5. 
${ }^{65}$ Ann McGrath, Born in the Cattle: Aborigines in Cattle Country (Sydney: Allen and Unwin, 1987), 142.

${ }^{66}$ Fiona Paisley, Loving Protection: Australian Feminism and Aboriginal Women's Rights, 1919-1939 (Melbourne: Melbourne University Press, 2000), 70-91.

67 'Half Caste Woman', Northern Standard, 1 February 1935.

${ }^{68}$ Auber Octavis Neville, Australia's Coloured Minority: Its Place in the Community (Sydney: Currawong Publishing Company, 1947), 183.

${ }^{69}$ Victoria Haskins, “A Better Chance'?-Sexual Abuse and the Apprenticeship of Aboriginal Girls under the Nsw Aborigines Protection Board', Aboriginal History 28 (2004): $33-5$.

${ }^{70}$ Ah Eng Lai, Peasants, Proletarians and Prostitutes: A Preliminary Investigation into the Work of Chinese Women in Colonial Malaya (Singapore: Institute of Southeast Asian Studies, 1986), 46-7.

${ }^{71}$ Susan Pederson, 'The Maternalist Movement in British Colonial Policy: The Controversy over “Child Slavery” in Hong Kong, 1917-1941', Past and Present, no. May (2001): 163. 72 'Mui Tsai in the Straits: Why It Must Be Banned by Statute', Straits Times, 27 January 1932.

${ }^{73}$ Lai, Peasants, Proletarians and Prostitutes, 50-3.

${ }^{74}$ Edith Picton-Turbervill, 'Minority Report', in Mui Tsai in Hong Kong and Malaya, ed. W.W. Woods and C.A. Willis (London: His Majesty's Stationary Office, 1937), 233. ${ }^{75}$ See, for example, 'Transcript of Interview with Miu Ling Lee', NAS: ACC 001917/02/03(1997), 37-8. The exception is Lucy Lum's account of her grandmother abuse of a mui tsai. Lucy Lum, The Thorn of Lion City: A Memoir (London: Fourth Estate, 2007), 160. 
${ }^{76}$ Janet Lim, Sold for Silver: An Autobiography of a Girl Sold into Slavery in Southeast Asia (Singapore: Monsoon Books, 2004), 35, 38.

${ }^{77}$ Maria Jaschok and Suzanne Miers, 'Women in the Chinese Patriarchal System:

Submission, Servitude, Escape and Collusion', in Women and Chinese Patriarchy:

Submission, Servitude and Escape, ed. Maria Jaschok and Suzanne Miers (Hong Kong: Hong Kong University Press, 1994), 9.

${ }^{78}$ On Hainanese houseboys, see 'The Limit: Lade Threatened with Axe by Hylam Servant', Malaya Tribune, 29 September 1922; 'End of the Assizes: Last Case Being Heard Today', Malaya Tribune, 25 January 1926. On white mistresses, see 'Labu Assault Case: European Lady Charged',Singapore Free Press and Mercantile Advertiser, 1 April 1924; 'Mem' Fined for Striking Cook',Straits Times, 19 June 1937. For violence by Eurasian men, see 'Girl Witness Collapses: Poignant Scences in Police Court, Eurasian on Murder Charge', Malaya Tribune, 17 January 1931; 'Amah's Alarming Experience: Eurasian's Escapade in Field', Straits Times, 8 January 1932.

79 'Cruelty to Mui Tsai: Story of a Callous Mistress, a Shocking Case', South China Morning Post, 9 May 1930.

${ }^{80}$ Victor Purcell, The Chinese in Malaya (London: Oxford University Press, 1948), 79, 181; Picton-Turbervill, 'Minority Report', 214, 231-3.

${ }^{81}$ Between the 1880 s and the 1930s, I located only two other newspaper accounts of assault of servants by Chinese employers.

82 ‘A Register of Girls', Straits Times, 19 August 1937; 'Sir George Maxwell on the Mui Tsai Problem II: "Registration Was Very Badly Done". "Worse in Malaya Than in Hong Kong", Straits Times, 6 August 1937.

${ }^{83}$ Lai, Peasants, Proletarians and Prostitutes, 53. 
${ }^{84}$ Sarah Paddle, 'The Limits of Sympathy: International Feminists and the Chinese "Slave Girl” Campaigns of the 1920s and 1930s', Journal of Colonialism and Colonial Studies 4, no. 3 (2003).

${ }^{85}$ Marriott, 'The Peoples of Singapore', 353, 360. 